\title{
Impact of Irrigation Water Deficit and Foliar Application with Salicylic Acid on the Productivity of Two Cowpea Cultivars
}

\author{
Dalia M. T. Nassef*, H.M.El-Aref** and Nadia M.K. Roshdi*** \\ *Department of Vegetable Crops, ** Department of Genetics, and***Department of \\ Soils and Water, Faculty of Agriculture, Assiut University, Assiut, Egypt.
}

\begin{abstract}
$\mathbf{T}$ THREE EXPERIMENTS were conducted at the Vegetable Experimental Farm, Faculty of Agriculture, Assiut University during two summer seasons 2015 and 2016 to study the effect of irrigation regime and salicylic acid foliar application on two cowpea cultivars. Each experiment subjected to one of three tested irrigation levels $(70,50$ and $30 \%$ of the available water which equal soil moisture tension of $0.35,0.60$ and 0.85 bar, respectively). Each experiment was laid out using strip plot arrangement in a randomized complete block design (RCBD) with three replications. Three salicylic levels $(0,150,300 \mathrm{ppm})$ were randomized in horizontal plots while the two cowpea cultivars (Azmirly and Cream 7) were allocated in vertical plots. The results showed that the irrigation water deficit significantly decreased all the studied traits. Concerning salicylic acid (SA) application, obtained data revealed that increasing the SA concentrations from 0 (control) to $300 \mathrm{ppm}$, increased the plant ability to withstand drought. Also, Azmirly cultivar was better than Cream 7 for all studied traits. The highest mean values of seed yield per hectar were obtained from Azmirly cultivar which was irrigated at $70 \%$ of the available water and sprayed with $300 \mathrm{ppm}$ salicylic acid as foliar application. Protein patterns were analyzed in leaves of Azmirly and Cream 7 cultivars to study the changes in gene expression after one and two weeks of treatments with 0,150 and $300 \mathrm{ppm}$ of salicylic acid (SA). SA induced the expression of 11 new proteins as compared to the control treatment.
\end{abstract}

Keywords: Cowpea, Water deficit, Salicylic acid, RWC, Seed yield (kg/hectare), WUE, Protein patterns and Gene expression.

\section{Introduction}

Cowpea (Vigna unguiculata L. Walp.) is an essential legume mostly grown in arid and semiarid regions (Muchero et al., 2009 and Afshari et al., 2013). It is usually better modified to water, heat and other biotic stresses compared with the other crops (Ehlers \& Hall, 1997, Kuykendall et al., 2000 and Martins et al., 2003). In contrast, Turk et al. (1980) showed that it has a highly subtle to drought at the flowering and pod-filling stages. It is clear that the sensitivity of cowpea returns to water stress during different growth stages has not been sufficiently established.

Water deficit is one of the main factors limiting crop production (Mohamed, 1996, 1999). It decreases growth, interrupts water relations, and reduces water use efficiency in crops (Mohamed \& Tawfik, 2007 and Farooq et al., 2012). Also, it reduces cell division rate and elongation, leaf size, stem expansion and root spread, and stomatal opening, as well as, water use efficiency (WUE), (Mohamed, 2003, Farooq et al., 2009 and Li et al., 2009).

Considerable differences among cowpea genotypes with regard to water stress tolerance were found. Also, cowpea genotypes differed significantly in number of pods and seed index which considered the most important traits for seed yield production under water deficit conditions (Faisal and Suliman, 2010). Also, many cowpea cultivars are affected by drought and high temperatures, especially at flowering stage (Dadson et al., 2005) and resulted in mainly reduction in productivity (Nielsen \& Hall, 1985, Dow El-Madina \& Hall, 1986 and Patel \& Hall, 1990). Hence, there is a need for cowpea genotypes, that are more tolerant to drought and 
efficient in their water use (Anyia and Herzog, 2004).

Salicylic acid is one of the most important plant growth regulators which rises plant greenhouse or in open field (Larque-saavedra and Martinmex, 2007). Also, it plays an important role in seed germination, transpiration, stomatal closure, glycolysis, flowering and fruit yield, (Raskin,1992, Klessig \& Malamy, 1994 and Sadoun et al., 2016), and heat tolerance (Dat et al., 1998 a, b). Furthermore, SA could be used as a potential growth regulator to enhance plant growth, under water deficit conditions (Janda et al., 2007).

The effects of spraying salicylic acid on plants show many physiological and molecular processes including changes in gene expression, increasing the protein synthesis and activation of specific enzymes (Bekheta \& Talaat, 2009 and Shakirova et al., 2003). However, Raskin (1992) reported that SA was categorized as endogenous growth regulator, a phytohormone which participates in regulation of plant growth and development. It can regulate ion transport and uptake (Kaydan et al., 2007), stomatal function (Raskin, 1992), increase stress tolerance and disease resistance (Klessig \& Malamy 1994 and Ghorbani Javid et al., 2011) and finally enhance plant growth and yield. Electrophoretic protein profiles were used to detect changes in gene expression, in which presence or absence of protein bands as well as increasing or decreasing of band intensity reflect the change in gene expression (Khavkin \& Zabrodina, 1994 and El-Aref, 2002).

The objective of this study was to evaluate the effects of irrigation water deficit and foliar application of salicylic acid on the productivity of two cowpea cultivars.

\section{Materials and Methods}

To study the effects of irrigation deficit and salicylic acid concentrations on two cowpea cultivars, three experiments were conducted at the Vegetable Experimental Farm, Faculty of Agriculture, Assiut University during two summer seasons 2015 and 2016. Each experiment was subjected to one irrigation level of the three levels 70,50 and $30 \%$ of the available water which equal to soil moisture tension of $0.35,0.60$ and 0.85 bar, respectively. Each experiment was laid out using strip plot arrangement in a randomized complete block design (RCBD) with three replications. Three salicylic acid levels $(0,150,300 \mathrm{ppm})$ were arranged in the horizontal plots while the two cowpea cultivars (Azmirly and Cream 7) were allocated in the vertical one. Planting distance was $60 \mathrm{~cm} \times 30 \mathrm{~cm}$ (Hasan, 2002, Agbogidi and Egho, 2012). The experimental unit area was 5.40 $\mathrm{m}^{2}$ (3 rows $60 \mathrm{~cm}$ apart and 3-meter-long with 30 $\mathrm{cm}$ distance between hills producing about 52888 plant per hectare). The soil physical and chemical properties of experimental site are presented in Table 1 (Page et al., 1982).

TABLE1. Analysis of physical and chemical characteristics of the experimental soil.

\begin{tabular}{|c|c|c|c|}
\hline Characteristic & Values & Characteristic & Values \\
\hline $\mathrm{pH}(1: 2.5)$ & 8.01 & Caly \% & 48.95 \\
\hline $\mathrm{EC} 1: 1 \mathrm{dSm}^{-1}$ & 1.20 & Silt \% & 29.37 \\
\hline $\mathrm{ECe} \mathrm{dSm}^{-1}$ & 1.85 & Sand $\%$ & 21.68 \\
\hline Soluble Cations, (meq/kg soil ) & & Soil texture & Clay \\
\hline $\mathrm{Ca}^{2+}$ & 9.00 & Bulk density, $\left(\mathrm{g} / \mathrm{cm}^{3}\right)$ & 1.70 \\
\hline $\mathrm{Mg}^{2+}$ & 3.00 & Field capacity, (F.C)\% & 42.40 \\
\hline $\mathrm{Na}^{+}$ & 6.50 & Wilting point (W.P)\% & 22.33 \\
\hline $\mathrm{K}^{+}$ & 1.00 & *Available soil moisture \% & 20.07 \\
\hline Soluble Anions,(meq/kg soil) & & W.Saturation \% & 65.01 \\
\hline $\mathrm{Cl}^{-}$ & 4.00 & \multirow{2}{*}{$\begin{array}{c}\text { Soil depth (cm) used in this } \\
\text { study }\end{array}$} & \multirow[t]{2}{*}{ Bulk density $\left(\mathrm{kg} / \mathrm{m}^{3}\right)$} \\
\hline $\mathrm{HCO}_{3}{ }^{-}+\mathrm{CO}_{3}{ }^{2-}$ & 6.50 & & \\
\hline $\mathrm{SO}_{4}^{2-}$ & 9.00 & $0-15$ & 1610.00 \\
\hline Total nitrogen (ppm) & 8.00 & $15-30$ & 1650.00 \\
\hline Available Phosphorus (ppm) & 11.20 & $30-45$ & 1720.00 \\
\hline Available Potassium (ppm) & 300.00 & $45-60$ & 1740.00 \\
\hline
\end{tabular}

*Available soil moisture (ASM) calculated as the difference between the field capacity, (F.C) \% and the wilting point (W.P) \%. 
The cowpea seeds were sown on $30^{\text {th }}$ April and $5^{\text {th }}$ May in the first and second seasons, respectively. The plants were sprayed to the drip point with salicylic acid as foliar application once after 30 days from sowing using plastic sheet onemeter height as a separator between treatments. Untreated plants were sprayed with tap water. All the other agricultural practices were done as recommended for cowpea by the Egyptian Ministry of Agriculture (CAAE, 2012).

In this study deficit irrigation strategies were applied to detect the difference between two cowpea cultivars to water shortage. Three deficit irrigation regimes were applied as follows:

- Irrigation water was applied after $30 \%$ of soil moisture depletion (SMD) or at $70 \%$ of the available soil moisture (70\% ASM).

- Irrigation was applied after depletion of 50\% (SMD) or at $50 \%$ of the available soil water (ASM).

- Irrigation was applied at $30 \%$ of the available soil moisture (ASM) (the stress treatment) or $70 \%$ of the soil moisture depletion (SMD).

The irrigation due time was detected by using soil tensiometers which was caliparated to achieve the above mentioned soil moister levels. The $70,50,30 \%$ ASM matched $0.35,0.60$ and 0.85 bar, respectively. Three tensiometers, (Irrometer Reg. U.S. PAT off moisture Indicator. Irrometer Company Riversid, CALIF., USA) were refilled with oxygen free water and closed tightly without any air puppies inside after each irrigation and inserted at depth of $30 \mathrm{~cm}$ in the root zone in each experiment. The surface irrigation system was used. The consumed water during each season was calculated by measuring the difference in the soil moisture before and after each irrigation in four soil depths $(0-15,15-30,30-45$, and 45-60 $\mathrm{cm})$ according to the following equation:

\section{Calculation of water consumptive use (CU)}

Actual evapotranspiration was estimated by the sampling method and calculated according to the following formulas:

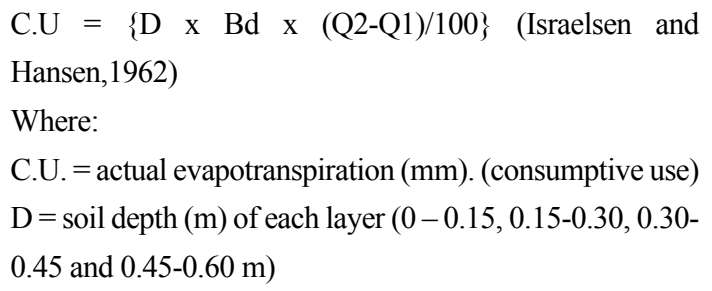

$\mathrm{Bd}=$ bulk density of soil (ton $/ \mathrm{m}^{3}$ ) for each layer.

Q2 = the percentage of soil moisture one day after irrigation (field capacity)

Q1 = the percentage of soil moisture before next irrigation

The applied water in the three experiments were 6906.67, 5340.72 and $3772.30 \mathrm{~m}^{3}$ ha $^{-1}$ during the first season and $8898.82,6309.38$ and $3717.56 \mathrm{~m}^{3}$ ha ${ }^{-1}$ during the second season for $70 \%, 50 \%$ and $30 \%$ ASM, respectively.

Also, reference evapotranspiration (ETo) was calculated using the meteorological data (Penman Monteith equation) as applied by CROPWAT model (Smith, 1991) as follows:

$$
\mathrm{ET}_{0}=\frac{\left[o .408 \times(R n-G)+\gamma\left[\frac{900}{T+273} U 2(e a-e d)\right]\right]}{\Delta+\gamma(1+0.34 U 2)}
$$

Where:

ETo: reference evapotranspiration $\left[\mathrm{mm} \mathrm{day}^{-1}\right]$,

$\mathrm{Rn}$ : net radiation at the crop surface [MJ m $\mathrm{m}^{-2} \mathrm{day}^{-1}$,

G: soil heat flux density [MJ m${ }^{-2}$ day $^{-1}$,

$\mathrm{T}$ : mean daily air temperature at $2 \mathrm{~m}$ height $\left[{ }^{\circ} \mathrm{C}\right]$,

$\mathrm{U} 2$ : wind speed at $2 \mathrm{~m}$ height $\left[\mathrm{ms}^{-1}\right]$,

es ed: saturation vapour pressure $[\mathrm{kPa}]$,

ea: actual vapour pressure $[\mathrm{kPa}]$,

es ed - ea: saturation vapour pressure deficit $[\mathrm{kPa}]$,

$\Delta$ : slope vapour pressure curve $\left[\mathrm{kPa}^{\circ} \mathrm{C}^{-1}\right]$,

$\gamma$ : psychrometric constant $\left[\mathrm{kPa}^{\circ} \mathrm{C}^{-1}\right]$.

The amount of applied water was matched the values calculated by Cropwat program as shown in Table 2 after using the cowpea crop factor $(\mathrm{Kc})$ and the four growth stages periods and irrigation application efficiency.

The measurements were recorded on ten guarded plants in each experimental unit as follows:

- Relative water content (RWC\%) were calculated as follows as described by Barr and Weatherly (1962). Ten leaf discs excised using a 1-centimetre-diameter cork borer were used for the measurements. 
TABLE 2. Meteorological data used to calculate evapotranspiration according to penman- monteth, (Smith, 1991).

\begin{tabular}{|c|c|c|c|c|c|c|}
\hline Year & Month & $\mathrm{T} \max \left({ }^{\circ} \mathrm{C}\right)$ & $\mathrm{T} \min \left({ }^{\circ} \mathrm{C}\right)$ & RH \% & W.S ( km/day) & ETo (mm/day) \\
\hline \multirow{12}{*}{2015} & January & 20.5 & 5.5 & 44.0 & 191.9 & 1.7 \\
\hline & February & 22.7 & 7.6 & 38.8 & 196.8 & 2.3 \\
\hline & March & 27.2 & 12.2 & 34.0 & 232.6 & 3.9 \\
\hline & April & 29.3 & 14.6 & 25.6 & 238.3 & 5.1 \\
\hline & May & 35.5 & 19.7 & 27.1 & 208.8 & 5.9 \\
\hline & June & 36.6 & 21.3 & 37.4 & 156.3 & 7.0 \\
\hline & July & 38.8 & 22.8 & 35.9 & 98.4 & 6.7 \\
\hline & August & 40.3 & 24.8 & 38.6 & 100.8 & 6.8 \\
\hline & September & 38.5 & 23.8 & 38.5 & 175.2 & 5.0 \\
\hline & October & 33.0 & 19.5 & 51.3 & 195.6 & 4.0 \\
\hline & November & 26.3 & 13.2 & 59.5 & 182.4 & 2.5 \\
\hline & December & 20.4 & 7.2 & 63.2 & 201.6 & 1.8 \\
\hline \multirow{12}{*}{2016} & January & 19.0 & 5.1 & 60.3 & 348.0 & 1.7 \\
\hline & February & 24.5 & 8.3 & 50.7 & 408.0 & 2.6 \\
\hline & March & 28.0 & 13.1 & 41.0 & 408.0 & 3.4 \\
\hline & April & 35.1 & 17.1 & 31.5 & 487.2 & 4.3 \\
\hline & May & 36.1 & 20.0 & 27.7 & 468.0 & 6.6 \\
\hline & June & 40.7 & 24.6 & 28.0 & 468.0 & 7.4 \\
\hline & July & 37.4 & 24.1 & 37.9 & 468.0 & 7.1 \\
\hline & August & 37.5 & 24.1 & 36.8 & 520.8 & 6.7 \\
\hline & September & 35.0 & 21.6 & 43.5 & 460.8 & 6.2 \\
\hline & October & 32.8 & 17.7 & 49.5 & 362.4 & 4.6 \\
\hline & November & 27.0 & 12.7 & 54.7 & 403.2 & 2.5 \\
\hline & December & 19.9 & 6.3 & 59.7 & 348.0 & 1.7 \\
\hline
\end{tabular}

$\mathrm{T} \min =$ monthly average minimum temperature

$\mathrm{RH} \%=$ Relative humidity

WS $=$ Wind speed $(\mathrm{km} /$ day $)$

ET0=Stander evapo- transpiration $(\mathrm{mm} /$ day $)$

RWC $(\%)=(F W-D W) /(T W-D W) \times 100$

Where:

$\mathrm{FW}=$ fresh weight of leaves

TW = turgid weight of leaves after incubating leaves in distilled water for $24 \mathrm{~h}$ in refrigerator

$\mathrm{DW}=$ dry weight of leaves after oven drying at $70{ }^{\circ} \mathrm{C}$ for $48 \mathrm{~h}$.

- Number of branches per plant at the end of the season

- $\quad$ One hundred seed weight (g) after drying

- $\quad$ Seed yield per plant (g)

- $\quad$ Seed yield (kg per hectare).

- Water use efficiency (WUE $\mathrm{kg} / \mathrm{m}^{3}$ ) as follows (Vites, 1965):
Water use efficiency $\left(\mathrm{kg} / \mathrm{m}^{3}\right)=\frac{\text { Seeds yield }\left(\mathrm{kgha}^{-1}\right)}{\text { Total water applied }\left(\mathrm{m}^{3} \mathrm{~h} \mathrm{c}^{-1}\right)}$

Each experiment was separately analyzed and bartlett test of error variances homogeneity was examined upon homogeneity combined analysis among the three studied irrigation treatments to detect the effect of irrigation factor and their interactions with the other tested factors. Collected data were analyzed using MSTAT-C Statistical Software Package (Michigan State University, Freed et al. 1991) and means were compared using the LSD at $\mathrm{P} \leq 0.05$ according to Gomez and Gomes (1984). Simple correlation coefficients among yield and its attributes traits over both seasons $(n=108)$ were also computed and studied. 


\section{Protein pattern analysis}

Leaf samples of Azmirly and Cream 7 cultivars were collected from the SA treated (150 and 300 ppm) and un-treated (control) plants after one and two weeks of treatment. Soluble proteins were extracted by crushing $1.0 \mathrm{~g}$ of each sample in 1.0 $\mathrm{ml}$ extraction buffer $(0.1 \mathrm{M}$ Tris- $\mathrm{HCl}+2.0 \mathrm{mM}$ EDTA, pH 7.8). Electrophoresis of soluble proteins was applied as described by Laemmli (1970) using $12 \%$ polyacrylamide and $1 \%$ SDS $(\mathrm{w} / \mathrm{v})$ under denaturing conditions. The gel was stained with Commassie Blue $\mathrm{R}$ and the detected bands were scored and molecular weights were determined against protein marker consisted of 70, 60, 50, 40, 30, 20 and $10 \mathrm{KD}$ using GS 365 electrophoresis data system program version 3.01 (Microsoft Windows@ version).

\section{Results and Discussion}

Relative water content (RWC) \%

Collected data reveal that the irrigation, salicylic and cowpea cultivars had a significant effect on RWC \% in both seasons (Table 3). But, the all interactions involved in this respect were not significant in both seasons. The highest mean values of RWC were obtained from irrigation at $70 \%$ of the available water (ASM) with no significant differences between this irrigation treatment and irrigation at $50 \%$ of available water (ASM) in both seasons. While, the significant lowest mean values of RWC (72.43 and 68.57\% in the first and second seasons, respectively) were recorded when irrigation was done at $30 \%$ of available water. A high quantity of leaves relative water content was found in some of the cowpea genotypes due to stomata closure and a leaf area reduction (Anyia \& Herzog 2004 and Afshari et al., 2013). Furthermore, the data reveal that salicylic acid significantly increased RWC trait in favor of high level (300 ppm) in both seasons. While, the lowest mean values of RWC were obtained from the control treatment with value of 73.12 and 69.85 in the first and second seasons, respectively. Larque-saavedra and Martin-mex, (2007) stated that SA enhanced rooting and root growth and development. Moreover, the data show that plants of Azmirly cultivar had significant contents of relative water as compared with Cream 7 cultivar in both seasons.

\section{Number of branches per plant}

Data illustrated in Table 4 show that the irrigation water deficit had a highly significant influence on the number of branches per plant in both seasons. Irrigation at $70 \%$ of available water (ASM) produced the highest mean values of 6.72 and 5.97 branch per plant in the first and second seasons, respectively. While, the lowest mean values in this respect were 5.00 and 3.87 branch per plant in the first and second seasons, respectively, were obtained when irrigation was applied at $30 \%$ of available water (ASM). This is explained by the shortage of irrigation water caused a reduction in nutrients uptake, metabolism translocation as well as cell devission and elongation which decreased number of branches per plant (Nonami,1998 and Farooq et al., 2009). Furthermore, data reveal that salicylic acid had a significant effect on number of branches per plant in both seasons. The 300 ppm SA concentration recorded the highest mean values of branches number per plant (6.42 and $5.61)$ in the first and second seasons, respectively. SA was reported to increase the shoot growth in many crop species (Larque-saavedra and Martinmex, 2007). Similar trend was obtained in mung bean by Ali and Mohamed, (2013). Moreover, the obtained data show that the studied cowpea cultivars varied significantly in this trait in both seasons. Azmirly cultivar surpassed the Cream 7 in this respect by 40.62 and $30.09 \%$ in the first and second season, respectively. This may be due to the genotypic, environmental interaction (Hanaa and Ali, 2011).All the interactions involved in this respect were not significant in both seasons.

\section{One hundred seed weight (g)}

Data exhibited in Table 5 show that the irrigation water deficit had a highly significant influence on the 100 seed weight in both seasons. Thus, irrigation at $70 \%$ of available water (ASM) resulted in the highest mean values of the hundred seed weight $(20.20 \mathrm{~g}$ and $16.36 \mathrm{~g}$ in the first and second seasons, respectively). While, the lowest mean values of 18.11 and $14.07 \mathrm{~g}$ for 
100 seed weight in the first and second seasons, respectively, were obtained when irrigation was applied at $30 \%$ of available water (ASM). The shortage of irrigation water caused inhabitation of metabolism products translocation from the source to sink (seeds) which resulted in lower seed weight. Similar trend was obtained by Umebese and Bankole (2013). Also, data reveal that salicylic acid had a highly significant effect on the 100 seed weight in both seasons. The highest mean value of the 100 seed weight (20.28 and 16.53 in the first and second seasons, respectively) was in favor of 300 ppm treatment. Similar result was reported by Afshari et al. (2013). Moreover, the obtained data show that the studied cowpea cultivars varied significantly in the 100 seed weight in the two growing seasons. Azmirly cultivar surpassed the Cream 7 one in this respect by 17.37 and 27.84 $\%$ in the first and second seasons, respectively. This is logic since the Azmirly cultivar surpassed the other one in regards to relative water content and number of branches per plant. This may increase the sources of metabolism translocation into the sink (seeds) and consequently increased seed weight. Also, the first order interaction between $\mathrm{SA} \times \mathrm{CV}$ was significant in both seasons and the interaction between (I x CV) was highly significant in the second season only. However, the second order interaction ( $\mathrm{I} \times \mathrm{SA} \times \mathrm{CV}$ ) was not significant in both seasons.

\section{Seed weight per plant ( $g$ )}

Concerning the effect of irrigation water deficit, salicylic acid, cultivars and their interactions, data in Table 6 revealed a highly significant effect on the seed weight per plant in the two growing seasons except the interaction between (SA $x$ $\mathrm{CV}$ ) in the second season only which was not significant. Thus, decreasing the amount of water applied to cowpea plants from 70 to 50 or $30 \%$ of available water (ASM) resulted in reduction in seed weight per plant by 21.08 and $37.89 \%$ in the first season, being 21.00 and $38.23 \%$ in the second season, respectively. The same trend was observed as it was for the 100 seed weight character. Also, the obtained data show that the superiority of spraying with 300 ppm SA over the other SA treatments in both seasons and produced the highest mean which were 38.57 and $36.90 \mathrm{~g}$ in the first and second seasons, respectively. This is to be expected since the same trend was true with regard to the 100 seed weight character. Furthermore, Azmirly cultivar surpassed Cream 7 in this respect by $14.10 \%$ and $14.89 \%$ in the first and second seasons, respectively. The same cultivar produced the highest mean value of 100 seed weight and consequently produced the highest seed weight per plant. Also, from the results, it is clear that Azmirly cultivar plants which were irrigated at $70 \%$ of available water (ASM) and sprayed with 300 ppm salicylic acid gave the highest seed weight per plant in both seasons (49.20 and $47.50 \mathrm{~g}$ in the first and second season, respectively). On the other hand, Cream 7 plants which were subjected to high water deficit (30\% of available water) and sprayed with tap water (without salicylic) gave the lowest weight of seeds per plant in both seasons (23.00 and 22.5 $\mathrm{g}$ in the first and second season, respectively).

\section{Seed yield $(\mathrm{kg} / \mathrm{ha})$}

Data in Table 7 denote that irrigation water deficit, salicylic acid, cultivars and their interactions had a significant effect on the seed yield ( $\mathrm{kg} / \mathrm{ha}$ ) in both seasons except the interaction between Salicylic acid and cultivars (SA $x \mathrm{CV}$ ) in the second season only. Irrigation at $70 \%$ of available water (ASM) surpassed the other two tested irrigation treatments in this respect. It produced 2447.9 and $2363.8 \mathrm{~kg} / \mathrm{ha}$ in the first and second seasons, respectively. Ogbonnaya et al. (2003) found that cowpea seed yield was reduced by about $60-71 \%$ as a result of water deficit. Water deficit led to yield reduction which depends on the severity and duration of the stress period. A similar result was obtained by Faisal and suliman, (2010). This can be logic since the same trend was observed for seed yield per plant. Also, the obtained data show the superiority of spraying with $300 \mathrm{ppm}$ SA over 150 and zero ppm SA treatments in both seasons and produced the highest mean values of 2142.5 and $2050.4 \mathrm{~kg} / \mathrm{ha}$ in the first and second seasons, respectively. This is to be expected since the same 
trend was true with regard to seed yield per plant. Moreover, Azmirly cultivar surpassed Cream 7 one by 14.08 and $14.87 \%$ in the first and second seasons, respectively. This is to be expected since the Azmirly cultivar produced the highest mean values with regard to seed yield per plant and consequently produced the highest seed yield per hectar. The same results were reported by Faisal and Suliman, (2010). Concerning the second order interaction, data obtained from these results clearly showed that that Azmirly cultivar plants which irrigated at $70 \%$ of available water (ASM) and sprayed with $300 \mathrm{ppm}$ salicylic acid gave the highest seed yield $\mathrm{kg} / \mathrm{ha}$ in both seasons of (2732.5 and $2640.0 \mathrm{~kg} / \mathrm{ha}$ in the first and second seasons, respectively. On the other hand, Cream 7 plants which subjected to a water deficit as irrigated at $30 \%$ of available water (ASM) and sprayed with tap water (without salicylic) gave the lowest seed yield $(\mathrm{kg} / \mathrm{ha})$ in both seasons with values of 1277.5 and $1250.0(\mathrm{~kg} / \mathrm{ha})$ in the first and second seasons, respectively. This is to be expected since the same interaction had a similar trend regarding the seed yield per plant in both seasons.

\section{Water use efficiency (WUE $\mathrm{kg} / \mathrm{m}^{3}$ )}

The obtained data (Table 8) show that irrigation water deficit, salicylic acid, cultivars and their interactions had a highly significant effect on water use efficiency (WUE $\mathrm{kg} / \mathrm{m}^{3}$ ) in both seasons except the interaction between salicylic acid and cultivars (SA x CV) as well as the second order interaction ( $\mathrm{x} \mathrm{SA} \times \mathrm{CV}$ ) in the second season only. One cubic meter $\left(\mathrm{m}^{3}\right)$ of water produced the highest yield when $30 \%$ of available water (ASM) used in both seasons with values of 0.408 and $0.393 \mathrm{~kg} / \mathrm{m}^{3}$ in the first and second seasons, respectively. Abbate et al. (2004) and Subramanian et al. (2006) reported higher WUE in wheat and tomato under water stress than well irrigated due to transpiration reduction. Also, the highest mean values of water use efficiency (WUE $\mathrm{kg} / \mathrm{m}^{3}$ ) were obtained from plants treated with $300 \mathrm{ppm}$ salicylic acid in both seasons of 0.408 and $0.345 \mathrm{~kg} / \mathrm{m}^{3}$ in the first and second seasons, respectively. This is logic since the same salicylic concentration produced the highest seed yield per hectare. That may be due to the effect of salicylic acid on stomata closure. Also, Azmirly cultivar surpassed cream 7 in water use efficiency (WUE) in both seasons with value of 0.400 and $0.341 \mathrm{~kg} / \mathrm{m}^{3}$ in the first and second seasons, respectively, this is also expected since Azmirly cultivar surpassed Cream 7 in seed yield per hectare and consequently increased WUE. Similar trend was found by Gwathmey \& Hall (1992) and Hall (2004). From these data, it was found that Azmirly cultivar which treated with $300 \mathrm{ppm}$ salicylic acid and irrigated at $30 \%$ of available water (ASM) produced the highest mean value of water use efficiency (WUE) with value of 0.464 and $0.455 \mathrm{~kg} / \mathrm{m}^{3}$ in first and second seasons, respectively.

The correlation coefficient among the studied characters over both seasons

Data presented in Table 9 show highly positive significant correlation between number of branches per plant, 100 seed weight and seed yield per plant with seed yield per hectare. That means the treatment which increased these traits led to increase the seed yield per hectare.

\section{Electrophoretic changes of protein patterns}

Electrophoretic Changes of protein patterns were analyzed in leaves of Azmirly and Cream 7 cultivars (Fig. 1 and 2), in order to follow the possible alterations in gene expression in leaves of cowpea plants after one and two weeks of spraying with 0, 150 and 300 ppm salicylic acid (SA). Protein profiles of these treatments are summarized in Tables 10 and 11 and illustrated in Fig. 1 and 2. The most noticeable change in protein patterns is that SA induced and enhanced protein synthesis, as compared to the control treatment.

After one week of spraying with SA, it was induced the appearance of four new polypeptides (21.1, 29.8, 46.1 and 50.2 KD) in Azmirly cultivar (Table 10). These proteins were induced with 300 ppm SA treatments, except the $50.2 \mathrm{KD}$ protein which was induced under both levels of 150 and $300 \mathrm{ppm}$ of SA. In case of Cream7 cultivar, four newly proteins at molecular weights $29.8,46.1$, 
50.2 and 57.6 KD were induced in 150 and 300 ppm SA treated plants while one band at 11.8 KD was newly expressed under high level of SA $(300 \mathrm{ppm})$. These results indicated that the three proteins 29.8, 46.1 and 50.2 KD were commonly induced in Azmirly and Cream 7 after one week of SA treatment, as compared to non-treated plants. Only one band at $42.3 \mathrm{KD}$ was reduced under low level of SA treatment in Cream7.

After two weeks of spraying with SA (Table 11), five proteins were newly expressed in Azmirly, two of them (29.8 and 86.4 KD) were induced by both 150 and 300 ppm SA treatments while the other bands (46.1, 54.8 and $76.3 \mathrm{KD}$ ) were induced by only $300 \mathrm{ppm}$ SA. In case of Cream7, the 29.8, 46.1 and 76.3 KD proteins were induced under both levels of SA while the three bands of 40.1, 54.8 and $65.4 \mathrm{KD}$ were induced under the $300 \mathrm{ppm}$ level of SA. These results revealed that four bands at 29.8, 46.1, 54.8 and 76.3 KD were commonly induced in both Azmirly and Cream7 cultivars after two weeks of SA treatment, as compared to non-treated plants. Only one band at $44.2 \mathrm{KD}$ was reduced in Cream7 under both treatments of SA.

It appears clearly that spraying with SA induced the expression of 11 proteins, four of them $(11.8,21.1,50.2$ and 57.6 KD) induced only after one week of treatment and five proteins (46.1, 54.8, 65.4, 76.3 and 86.4 KD) induced only after two weeks of SA treatment while, two new proteins (29.8 and 46.1KD) were expressed along the two periods of SA treatments. The results revealed that most proteins, including the low molecular weight (MW) proteins (e.g. 11.8 and 21.1 KD), which induced in the first week of SA treatment were down-regulated after two weeks while newly high MW proteins 65.4, 76.3 and $86.4 \mathrm{KD}$ were up-regulated after the second week of SA treatment.

The results of polyacrylamide gel electrophoresis indicated that the SA induced alternations in protein expression and 11 proteins were newly expressed as compared to the control treatment. Since SA increased plant growth and yield, these de novo syntheses of specific proteins may play an important role in the biochemical pathways to enhance plant growth and yield. These results reflect the potentiality of SA to enhance the expression of specific genes in the treated plants and enhanced a cascade biochemical reaction which might determine the ultimate appearance of growth patterns and yield (Jacobsen \& Beach, 1985, Raskin, 1992 and Abdel-Hamid, 2002). Songhai et al. (1999) found that treatment of rice with exogenous SA induces the expression of the genes resulting in an increased number of proteins, increases in some band densities, enhanced specific enzyme activity and strengthened resistance. Bekheta and Talaat (2009) reported that treatment of cowpea with bioregulator SA increased total protein and caused positive changes in protein expression which induced some proteins and reduced other proteins. In addition, Jalal et al. (2012) found that water stress and SA treatments in shara (Plectranthus tenuiflorus) plants induced new high molecular weight protein bands and reduced other proteins.

\section{Conclusion}

Azmirly cultivar which was irrigated at $70 \%$ of the available water and sprayed with $300 \mathrm{ppm}$ salicylic acid as foliar application produced the highest mean values of seed yield per hectare (2732.5 and $2640 \mathrm{~kg} /$ hectare in the first and second seasons, respectively). Also, SA induced the expression of 11 new proteins as compared to the control treatment. Since SA increased plant growth and yield, these de novo syntheses of specific proteins may play an important role in the biochemical pathways to enhance plant growth and yield. 
TABLE 3. Effect of irrigation deficit, salicylic acid application, cultivars and their interactions on relative water content (RWC).

\begin{tabular}{|c|c|c|c|c|c|c|c|c|c|}
\hline \multirow{2}{*}{$\begin{array}{c}\text { Season } \\
\text { Irrigation (I) }\end{array}$} & \multicolumn{5}{|c|}{2015} & \multicolumn{4}{|c|}{2016} \\
\hline & $\begin{array}{r}\begin{array}{r}\text { Salicylic acid } \\
\text { (SA) }\end{array} \\
\text { Cultivar ( CV) }\end{array}$ & $\begin{array}{c}\mathbf{0} \\
\mathrm{ppm}\end{array}$ & $\begin{array}{l}150 \\
\text { ppm }\end{array}$ & $\begin{array}{c}300 \\
\text { ppm }\end{array}$ & Mean & $\begin{array}{c}0 \\
\text { ppm }\end{array}$ & $\begin{array}{l}150 \\
\text { ppm }\end{array}$ & $\begin{array}{l}300 \\
\text { ppm }\end{array}$ & Mean \\
\hline \multirow{2}{*}{$\begin{array}{c}I_{1} \\
70 \% \text { of available water }\end{array}$} & $\mathrm{CV}_{1}($ Azmirly $)$ & 78.85 & 83.33 & 89.88 & 84.02 & 75.74 & 81.93 & 83.98 & 80.55 \\
\hline & $\mathrm{CV}_{2}($ Cream 7$)$ & 74.98 & 78.06 & 82.09 & 78.38 & 71.81 & 76.29 & 79.78 & 75.96 \\
\hline \multicolumn{2}{|r|}{ Mean } & 76.92 & 80.70 & 85.99 & 81.20 & 73.78 & 79.11 & 81.88 & 78.26 \\
\hline \multirow{2}{*}{$\begin{array}{c}\mathrm{I}_{2} \\
50 \% \text { of available water }\end{array}$} & $\mathrm{CV}_{1}$ ( Azmirly) & 75.23 & 78.61 & 81.91 & 78.58 & 72.51 & 74.54 & 78.38 & 75.15 \\
\hline & $\mathrm{CV}_{2}($ Cream 7$)$ & 71.66 & 75.39 & 78.89 & 75.31 & 69.62 & 72.08 & 75.55 & 72.42 \\
\hline \multicolumn{2}{|r|}{ Mean } & 73.45 & 77.00 & 80.39 & 76.95 & 71.07 & 73.31 & 76.97 & 73.78 \\
\hline \multirow{2}{*}{$\begin{array}{c}\mathrm{I}_{3} \\
30 \% \text { of available water }\end{array}$} & $\mathrm{CV}_{1}$ ( Azmirly) & 71.63 & 73.45 & 77.76 & 74.28 & 67.32 & 70.24 & 75.89 & 71.15 \\
\hline & $\mathrm{CV}_{2}($ Cream 7$)$ & 66.34 & 69.56 & 75.83 & 70.58 & 62.08 & 65.53 & 70.36 & 65.99 \\
\hline \multicolumn{2}{|r|}{ Mean } & 68.98 & 71.51 & 76.79 & 72.43 & 64.70 & 67.89 & 73.13 & 68.57 \\
\hline \multicolumn{2}{|c|}{ General Mean } & 73.12 & 76.40 & 81.06 & 76.86 & 69.85 & 73.44 & 77.32 & 73.54 \\
\hline \multirow{2}{*}{ CV x SA Interaction } & $\mathrm{CV}_{1}$ & 75.24 & 78.46 & 83.18 & 78.96 & 71.86 & 75.57 & 79.42 & 75.62 \\
\hline & $\mathrm{CV}_{2}$ & 70.99 & 74.34 & 78.94 & 74.76 & 67.84 & 71.30 & 75.23 & 71.46 \\
\hline & & \multicolumn{2}{|c|}{ F value } & \multicolumn{2}{|c|}{ LSD 0.05} & \multicolumn{2}{|c|}{$\mathrm{F}$ value } & \multicolumn{2}{|c|}{ LSD 0.05} \\
\hline \multicolumn{2}{|r|}{$\mathrm{I}$} & \multicolumn{2}{|c|}{ * } & \multicolumn{2}{|c|}{5.3001} & \multicolumn{2}{|c|}{ * } & \multicolumn{2}{|c|}{5.8158} \\
\hline \multicolumn{2}{|r|}{$\mathrm{SA}$} & \multicolumn{2}{|c|}{ * } & \multicolumn{2}{|c|}{5.4306} & \multicolumn{2}{|c|}{ * } & \multicolumn{2}{|c|}{5.1958} \\
\hline \multicolumn{2}{|r|}{$\mathrm{CV}$} & \multicolumn{2}{|c|}{ * } & \multicolumn{2}{|c|}{---- } & \multicolumn{2}{|c|}{$*$} & \multicolumn{2}{|c|}{----} \\
\hline \multicolumn{2}{|r|}{ I x SA } & \multicolumn{2}{|c|}{ N.S } & \multicolumn{2}{|c|}{----} & & & & \\
\hline & $\mathrm{IxCV}$ & & & & & & & & \\
\hline & $\mathrm{SAxCV}$ & & & & & & & & \\
\hline & $\mathrm{xSA} \times \mathrm{CV}$ & & & & & & & & \\
\hline
\end{tabular}

NS, * non-significant and significant at 0.05 probability level, respectively.

TABLE 4. Effect of irrigation deficit, salicylic acid application, cultivars and their interactions on number of branches per plant.

\begin{tabular}{|c|c|c|c|c|c|c|c|c|c|}
\hline \multirow{2}{*}{$\begin{array}{c}\text { Season } \\
\text { Irrigation (I) }\end{array}$} & \multicolumn{5}{|c|}{2015} & \multicolumn{4}{|c|}{2016} \\
\hline & \begin{tabular}{|cc} 
& $\begin{array}{c}\text { Salicylic acid } \\
\text { (SA) }\end{array}$ \\
Cultivar (CV) & \\
\end{tabular} & $\begin{array}{c}0 \\
\text { ppm }\end{array}$ & $\begin{array}{r}150 \\
\text { ppm }\end{array}$ & $\begin{array}{l}300 \\
\text { ppm }\end{array}$ & Mean & $\begin{array}{c}0 \\
\text { ppm }\end{array}$ & $\begin{array}{l}150 \\
\text { ppm }\end{array}$ & $\begin{array}{r}300 \\
\text { ppm }\end{array}$ & Mean \\
\hline $\begin{array}{c}I_{1} \\
70 \% \text { of available water }\end{array}$ & $\mathrm{CV}_{2}$ (Cream 7) & 5.00 & 5.29 & 6.08 & 5.46 & 4.63 & 5.13 & 5.92 & 5.23 \\
\hline \multicolumn{2}{|r|}{ Mean } & 6.25 & 6.73 & 7.17 & 6.72 & 5.53 & 5.89 & 6.50 & 5.97 \\
\hline $\begin{array}{c}\mathrm{I}_{2} \\
50 \% \text { of available water }\end{array}$ & $\mathrm{CV}_{1}$ (Azmirly) & 6.33 & 6.50 & 6.78 & 6.54 & 5.57 & 6.44 & 6.50 & 6.17 \\
\hline \multirow{2}{*}{$\begin{array}{c}\mathrm{I}_{3} \\
30 \% \text { of available water }\end{array}$} & $\mathrm{CV}_{1}$ (Azmirly) & 5.45 & 6.00 & 6.43 & 5.96 & 4.00 & 4.22 & 4.89 & 4.37 \\
\hline & $\mathrm{CV}_{2}($ Cream 7$)$ & 3.50 & 3.54 & 5.09 & 4.04 & 3.00 & 3.17 & 3.95 & 3.37 \\
\hline \multicolumn{2}{|r|}{ Mean } & 4.48 & 4.77 & 5.76 & 5.00 & 3.5 & 3.70 & 4.42 & 3.87 \\
\hline \multicolumn{2}{|c|}{ General Mean } & 5.40 & 5.69 & 6.42 & 5.84 & 4.65 & 4.99 & 5.61 & 5.08 \\
\hline CV x SA Interaction & $\mathrm{CV}_{1}$ & 6.43 & 6.89 & 7.15 & 6.82 & 5.33 & 5.77 & 6.16 & 5.75 \\
\hline \multicolumn{2}{|r|}{ SA } & \multicolumn{2}{|c|}{ * } & \multicolumn{2}{|c|}{0.5006} & \multicolumn{2}{|c|}{$* *$} & \multicolumn{2}{|c|}{0.3595} \\
\hline \multicolumn{2}{|r|}{$\mathrm{CV}$} & \multicolumn{2}{|c|}{ * } & \multicolumn{2}{|c|}{---- } & \multicolumn{2}{|c|}{$*$} & \multicolumn{2}{|c|}{---- } \\
\hline \multicolumn{2}{|r|}{$\mathrm{IxSA}$} & \multicolumn{2}{|c|}{ N.S } & \multicolumn{2}{|c|}{----} & & & & \\
\hline & $\mathrm{IxCV}$ & & & & & & & & \\
\hline & $\mathrm{SAxCV}$ & & & & & & & & \\
\hline & $\mathrm{xSA} \times \mathrm{CV}$ & & & & & & & & \\
\hline
\end{tabular}

NS, * and ** non-significant and significant at 0.05 and 0.01 probability level, respectively. 
TABLE 5. Effect of irrigation deficit, salicylic acid application, cultivars and their interactions on 100 seed weight (g).

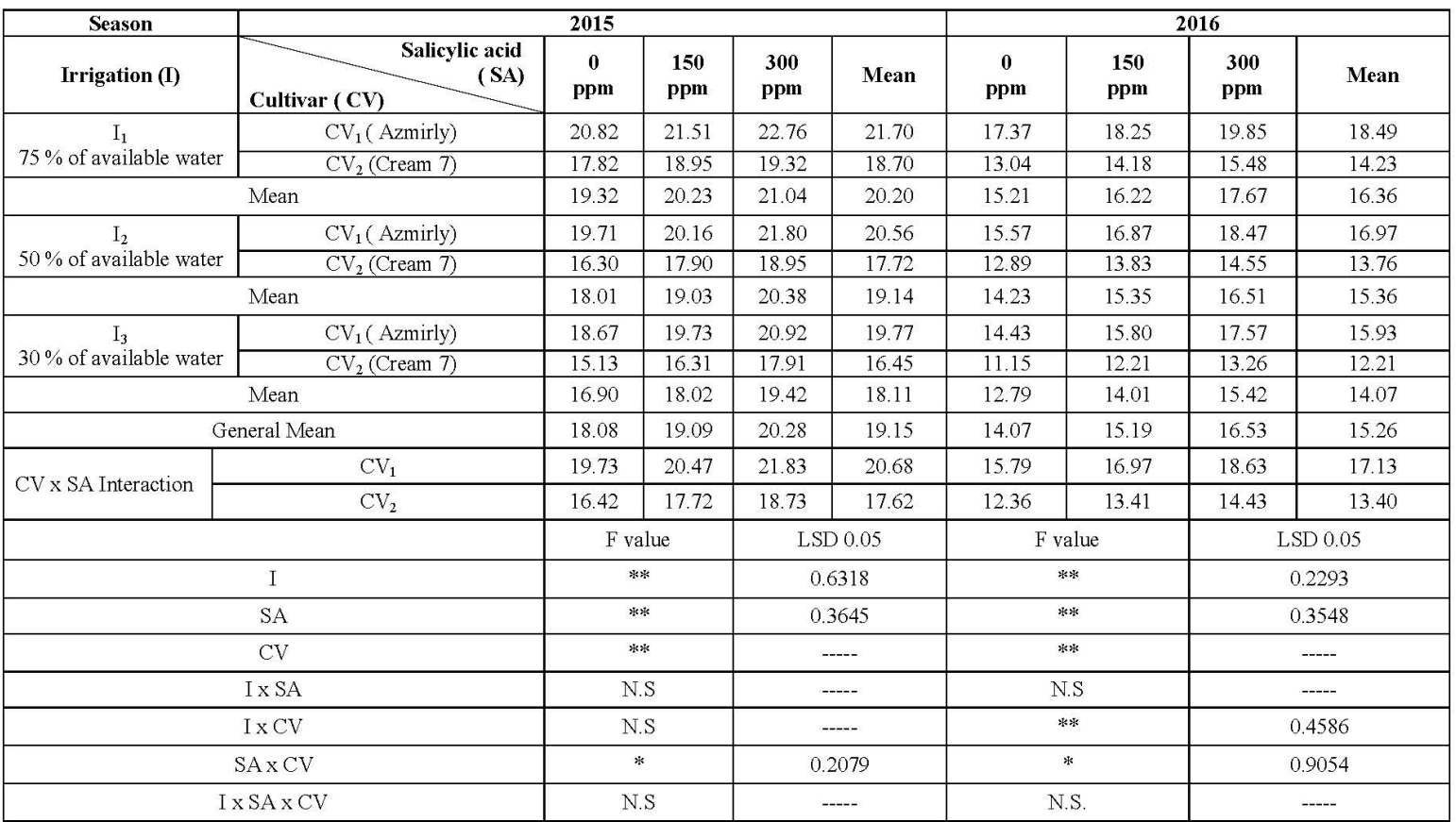

NS, * and ** non-significant and significant at 0.05 and 0.01 probability level, respectively.

TABLE 6. Effect of irrigation deficit, salicylic acid application, cultivars and their interactions on seed yield per plant (g).

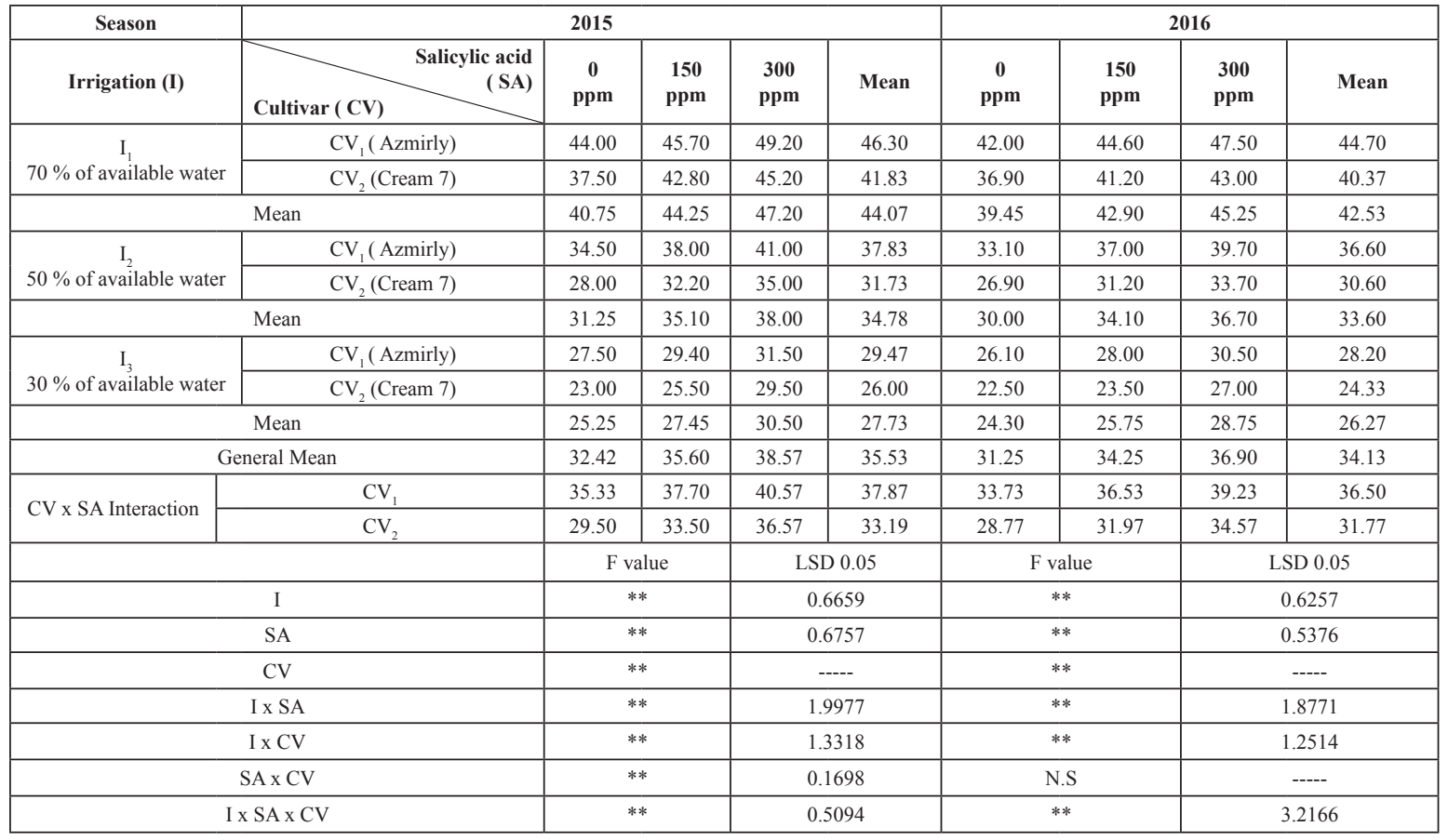

NS and ** non-significant and significant at 0.01 probability level, respectively. 
TABLE 7. Effect of irrigation deficit, salicylic acid application, cultivars and their interactions on seed yield ( $\mathrm{kg} / \mathrm{hectare)}$.

\begin{tabular}{|c|c|c|c|c|c|c|c|c|c|}
\hline Season & \multicolumn{5}{|c|}{2015} & \multicolumn{4}{|c|}{2016} \\
\hline Irrigation (I) & $\begin{array}{r}\text { Salicylic acid } \\
\text { ( SA) }\end{array}$ & $\begin{array}{c}\mathbf{0} \\
\text { ppm }\end{array}$ & $\begin{array}{l}150 \\
\text { ppm }\end{array}$ & $\begin{array}{l}300 \\
\text { ppm }\end{array}$ & Mean & $\begin{array}{c}\mathbf{0} \\
\text { ppm }\end{array}$ & $\begin{array}{l}150 \\
\text { ppm }\end{array}$ & $\begin{array}{l}300 \\
\text { ppm }\end{array}$ & Mean \\
\hline \multirow{2}{*}{$\begin{array}{c}\mathrm{I}_{1} \\
70 \% \text { of available water }\end{array}$} & $\mathrm{CV}_{1}$ ( Azmirly) & 2445.0 & 2540.0 & 2732.5 & 2572.5 & 2332.5 & 2477.5 & 2640.0 & 2483.3 \\
\hline & $\mathrm{CV}_{2}($ Cream 7$)$ & 2082.5 & 2377.5 & 2510.0 & 2323.3 & 2050.0 & 2292.5 & 2390.0 & 2244.2 \\
\hline \multicolumn{2}{|r|}{ Mean } & 2263.8 & 2458.8 & 2621.3 & 2447.9 & 2191.3 & 2385.0 & 2515.0 & 2363.8 \\
\hline \multirow{2}{*}{$\begin{array}{c}\mathrm{I}_{2} \\
50 \% \text { of available water }\end{array}$} & $\mathrm{CV}_{1}$ (Azmirly) & 1917.5 & 2110.0 & 2277.5 & 2101.7 & 1840.0 & 2055.0 & 2205.0 & 2033.3 \\
\hline & $\mathrm{CV}_{2}($ Cream 7) & 1555.0 & 1790.0 & 1945.0 & 1763.3 & 1495.0 & 1732.5 & 1872.5 & 1700.0 \\
\hline \multicolumn{2}{|r|}{ Mean } & 1736.3 & 1950.0 & 2111.3 & 1932.5 & 1667.5 & 1893.8 & 2038.8 & 1866.7 \\
\hline \multirow{2}{*}{$\begin{array}{l}\mathrm{I}_{3} \\
30 \% \text { of available water }\end{array}$} & $\mathrm{CV}_{1}$ (Azmirly) & 1527.5 & 1632.5 & 1750.0 & 1636.7 & 1450.0 & 1555.0 & 1695.0 & 1566.7 \\
\hline & $\mathrm{CV}_{2}($ Cream 7) & 1277.5 & 1417.5 & 1640.0 & 1445.0 & 1250.0 & 1305.0 & 1500.0 & 1351.7 \\
\hline \multicolumn{2}{|r|}{ Mean } & 1402.5 & 1525.0 & 1695.0 & 1540.8 & 1350.0 & 1430.0 & 1597.5 & 1459.2 \\
\hline \multicolumn{2}{|c|}{ General Mean } & 1800.8 & 1977.9 & 2142.5 & 1973.7 & 1736.3 & 1902.9 & 2050.4 & 1896.5 \\
\hline \multirow{2}{*}{ CV x SA Interaction } & $\mathrm{CV}_{1}$ & 1963.3 & 2094.2 & 2253.3 & 2103.6 & 1874.2 & 2029.2 & 2180.0 & 2027.8 \\
\hline & $\mathrm{CV}_{2}$ & 1638.3 & 1861.7 & 2031.7 & 1843.9 & 1598.3 & 1776.7 & 1920.8 & 1765.3 \\
\hline & & \multicolumn{2}{|c|}{$F$ value } & \multicolumn{2}{|c|}{ LSD 0.05} & \multicolumn{2}{|c|}{$\mathrm{F}$ value } & \multicolumn{2}{|c|}{ LSD 0.05} \\
\hline \multicolumn{2}{|r|}{ I } & \multicolumn{2}{|c|}{$* *$} & \multicolumn{2}{|c|}{42.991} & \multicolumn{2}{|c|}{$* *$} & \multicolumn{2}{|c|}{35.857} \\
\hline \multicolumn{2}{|r|}{ SA } & \multicolumn{2}{|c|}{$* *$} & \multicolumn{2}{|c|}{33.443} & \multicolumn{2}{|c|}{$* *$} & \multicolumn{2}{|c|}{16.134} \\
\hline \multicolumn{2}{|r|}{$\mathrm{CV}$} & \multicolumn{2}{|c|}{$* *$} & \multicolumn{2}{|c|}{----- } & \multicolumn{2}{|c|}{$* *$} & \multicolumn{2}{|c|}{----- } \\
\hline \multicolumn{2}{|r|}{ I x SA } & \multicolumn{2}{|c|}{$* *$} & \multicolumn{2}{|c|}{128.973} & \multicolumn{2}{|c|}{$* *$} & & \\
\hline & $\mathrm{I} \times \mathrm{CV}$ & & & & & & & & \\
\hline & SA x CV & & & & & & & & \\
\hline & $x \mathrm{SA} \times \mathrm{CV}$ & & & & 189 & & & & \\
\hline
\end{tabular}

NS and ** non-significant and significant at 0.01 probability level, respectively.

TABLE 8. Effect of irrigation deficit, salicylic acid application, cultivars and their interactions on water use efficiency (WUE $\mathrm{kg} / \mathrm{m}^{3}$ ):

\begin{tabular}{|c|c|c|c|c|c|c|c|c|c|}
\hline Season & \multicolumn{5}{|c|}{2015} & \multicolumn{4}{|c|}{2016} \\
\hline Irrigation (I) & $\begin{array}{rr}\text { Salicylic acid } \\
\text { ( SA) }\end{array}$ & $\begin{array}{c}\mathbf{0} \\
\text { ppm }\end{array}$ & $\begin{array}{l}150 \\
\text { ppm }\end{array}$ & $\begin{array}{l}300 \\
\text { ppm }\end{array}$ & Mean & $\begin{array}{c}\mathbf{0} \\
\text { ppm }\end{array}$ & $\begin{array}{l}150 \\
\text { ppm }\end{array}$ & $\begin{array}{l}300 \\
\text { ppm }\end{array}$ & Mean \\
\hline $\begin{array}{c}\mathrm{I}_{1} \\
70 \% \text { of available water }\end{array}$ & $\mathrm{CV}_{2}$ (Cream 7) & 0.302 & 0.344 & 0.363 & 0.336 & 0.230 & 0.258 & 0.269 & 0.252 \\
\hline \multicolumn{2}{|r|}{ Mean } & 0.328 & 0.356 & 0.380 & 0.354 & 0.246 & 0.268 & 0.283 & 0.266 \\
\hline $50 \%$ of available water & $\mathrm{CV}_{1}$ (Azmirly) & 0.359 & 0.395 & 0.426 & 0.394 & 0.292 & 0.326 & 0.349 & 0.322 \\
\hline \multicolumn{2}{|r|}{ Mean } & 0.325 & 0.365 & 0.395 & 0.362 & 0.264 & 0.300 & 0.323 & 0.296 \\
\hline \multirow{2}{*}{$\begin{array}{c}\mathrm{I}_{3} \\
30 \% \text { of available water }\end{array}$} & $\mathrm{CV}_{1}$ ( Azmirly) & 0.405 & 0.433 & 0.464 & 0.434 & 0.390 & 0.418 & 0.455 & 0.421 \\
\hline & $\mathrm{CV}_{2}$ (Cream 7) & 0.339 & 0.376 & 0.435 & 0.383 & 0.336 & 0.351 & 0.403 & 0.364 \\
\hline \multicolumn{2}{|r|}{ Mean } & 0.372 & 0.404 & 0.449 & 0.408 & 0.363 & 0.385 & 0.429 & 0.393 \\
\hline \multicolumn{2}{|c|}{ General Mean } & 0.342 & 0.375 & 0.408 & 0.375 & 0.291 & 0.318 & 0.345 & 0.318 \\
\hline \multicolumn{2}{|r|}{ I } & \multicolumn{2}{|c|}{$* *$} & \multicolumn{2}{|c|}{0.0022} & \multicolumn{2}{|c|}{$* *$} & \multicolumn{2}{|c|}{0.0065} \\
\hline \multicolumn{2}{|r|}{ SA } & \multicolumn{2}{|c|}{$* *$} & \multicolumn{2}{|c|}{0.0060} & \multicolumn{2}{|c|}{$* *$} & \multicolumn{2}{|c|}{0.0029} \\
\hline \multicolumn{2}{|r|}{$\mathrm{CV}$} & \multicolumn{2}{|c|}{$* *$} & \multicolumn{2}{|c|}{---- } & \multicolumn{2}{|c|}{$* *$} & \multicolumn{2}{|c|}{----- } \\
\hline \multicolumn{2}{|r|}{$\mathrm{I} \times \mathrm{SA}$} & \multicolumn{2}{|c|}{$* *$} & \multicolumn{2}{|c|}{0.0066} & \multicolumn{2}{|c|}{$* *$} & & \\
\hline & $\mathrm{I} \times \mathrm{CV}$ & & & & & & & & \\
\hline & $\mathrm{SA} \times \mathrm{CV}$ & & & & & & & & \\
\hline & $\mathrm{SA} \times \mathrm{CV}$ & & & & & & & & \\
\hline
\end{tabular}

NS and ** non-significant and significant at 0.01 probability level, respectively. 
TABLE 9. Correlation coefficients (Pearson Correlation) among different studied traits over both seasons $(\mathrm{n}=108)$.

\begin{tabular}{|c|c|c|c|c|}
\hline Characters & number of branches per plant & 100 seed weight $(\mathrm{g})$ & seed yield per plant (g) & seed yield (kg per hectare) \\
\hline number of branches per plant & -- & & & \\
\hline 100 seed weight $(\mathrm{g})$ & $0.78838^{* *}$ & -- & & \\
\hline seed yield per plant $(\mathrm{g})$ & $0.79063^{* *}$ & $0.61615^{* *}$ & -- & \\
\hline seed yield (kg per hectare) & $0.79161^{* *}$ & $0.61564 * *$ & $0.99856 * *$ & $\ldots$ \\
\hline
\end{tabular}

** significant at 0.01 probability.

TABLE 10. Molecular weights of protein bands detected in leaves of cowpea plants after one week of treatment with 0,150 and $300 \mathrm{ppm}$ salicylic acid (SA) (Data were obtained by GS 365 electrophoresis data system program version 3.01).

\begin{tabular}{|c|c|c|c|c|c|c|c|}
\hline \multirow{2}{*}{ Band No. } & \multirow{2}{*}{ KD } & \multicolumn{3}{|c|}{ Azmirly } & \multicolumn{3}{|c|}{ Cream 7} \\
\hline & & $0(p p m$ SA $)$ & 150(ppm SA) & $300(p p m$ SA $)$ & $0($ ppm SA $)$ & $150(p p m$ SA $)$ & 300(ppm SA $)$ \\
\hline 1 & 67.5 & + & + & + & + & + & + \\
\hline 2 & 65.4 & + & + & + & + & + & + \\
\hline 3 & 63.3 & + & + & + & + & + & + \\
\hline 4 & 60.1 & + & + & + & + & + & + \\
\hline 5 & 57.6 & + & + & + & - & + & + \\
\hline 6 & 54.8 & + & + & + & - & - & - \\
\hline 7 & 50.2 & - & + & + & - & + & + \\
\hline 8 & 46.1 & - & - & + & - & + & + \\
\hline 9 & 44.2 & + & + & + & + & + & + \\
\hline 10 & 42.3 & + & + & + & + & - & + \\
\hline 11 & 40.1 & + & + & + & + & + & + \\
\hline 12 & 36.1 & + & + & + & + & + & + \\
\hline 13 & 29.8 & - & - & + & - & + & + \\
\hline 14 & 27.2 & + & + & + & + & + & + \\
\hline 15 & 23.3 & + & + & + & + & + & + \\
\hline 16 & 21.1 & - & - & + & - & - & - \\
\hline 17 & 19.5 & + & + & + & + & + & + \\
\hline 18 & 14.2 & + & + & + & + & + & + \\
\hline 19 & 11.8 & + & + & + & - & - & + \\
\hline \multicolumn{2}{|c|}{ Number of bands } & 15 & 16 & 19 & 12 & 15 & 17 \\
\hline
\end{tabular}


TABLE 11. Molecular weights of protein bands detected inleaves ofcowpea plants after two weeks of treatment with 0,150 and 300 ppm salicylic acid (SA)(Data were obtained by GS 365 electrophoresis data system program version 3.01).

\begin{tabular}{|c|c|c|c|c|c|c|c|}
\hline \multirow{2}{*}{ Band No. } & \multirow{2}{*}{ KD } & \multicolumn{3}{|c|}{ Azmirly } & \multicolumn{3}{|c|}{ Cream 7} \\
\hline & & 0 (ppm SA) & 150(ppm SA) & 300(ppm SA) & 0(ppm SA) & 150(ppm SA) & 300(ppm SA) \\
\hline 1 & 88.7 & + & + & + & + & + & + \\
\hline 2 & 86.4 & - & + & + & - & - & - \\
\hline 3 & 80.2 & + & + & + & + & + & + \\
\hline 4 & 76.3 & - & - & + & - & + & + \\
\hline 5 & 67.5 & + & + & + & + & + & + \\
\hline 8 & 57.6 & + & + & + & + & + & + \\
\hline 9 & 54.8 & - & - & + & - & - & + \\
\hline 10 & 46.1 & - & - & + & - & + & + \\
\hline 11 & 44.2 & + & + & + & + & - & - \\
\hline 12 & 40.1 & - & - & - & - & - & + \\
\hline 16 & 23.3 & + & + & + & + & + & + \\
\hline 17 & 19.5 & + & + & + & + & + & + \\
\hline 18 & 14.2 & + & + & + & + & + & + \\
\hline 19 & 11.8 & + & + & + & + & + & + \\
\hline \multicolumn{2}{|c|}{ Number of bands } & 13 & 14 & 17 & 12 & 14 & 17 \\
\hline
\end{tabular}

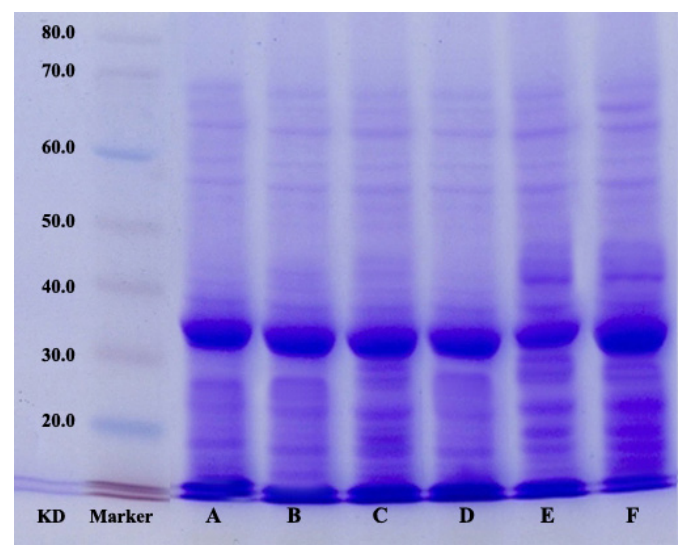

Fig. 1. SDS-polyacrylamide gel electrophoresis for protein profiles detected in leaves of cowpea plants after one week of treatment with 0 , 150 and 300 ppm salicylic acid (SA). Where: protein marker in lane-1, Azmirly in lanes $A$ (0 ppm SA), B (150 ppm SA) and C (300 ppm SA), and Cream 7 in lanes D (0 ppm SA), E (150 ppm SA) and F (300 ppm SA).

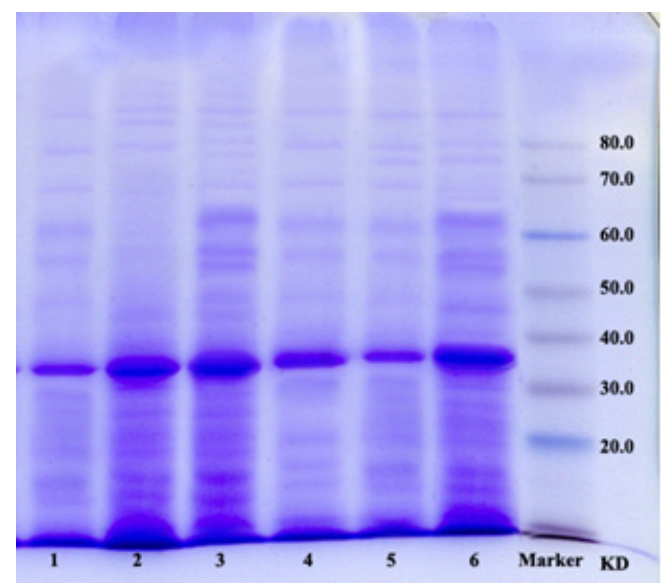

Fig. 2. SDS-polyacrylamide gel electrophoresis for protein profiles detected in leaves of cowpea plants after two weeks of treatment with 0 , 150 and 300 ppm salicylic acid (SA). Where: protein marker in lane-1, Azmirly in lanes 1 (0 ppm SA), 2 (150 ppm SA) and 3 (300 ppm SA), and Cream 7 in lanes 4 (0 ppm SA), 5 (150 ppm SA) and 6 (300 ppm SA). 


\section{$\underline{\text { References }}$}

Abbate, P.E., Dardanellib, J.L., Cantareroc, M.G., Maturanoc, M., Melchiorid, R.J.M., Sueroa, E.E. (2004) Climatic and water availability effects on water-use efficiency in wheat. Crop Sci., 44, 474-483.

Abdel-Hamid, M., (2002) Effect of seeds soaking in paclobutrazole on growth parameters, productivity, photosynthetic pigments, ion content of faba bean, chemical composition and protein profile of the harvested seeds. Egypt. J. Biotechnol., 11, 48-70.

Afshari, M., Shekari, F., Azimkhani, R., Habibi, H. and Fotokian, M.H. (2013) Effects of foliar application of salicylic acid on growth and Physiological attributes of cowpea under water stress Conditions. Iran Agricultural Research, Vol. 32, No. 1.

Agbogidi, O.M. and Egho, E.O. (2012) Evaluation of eight varieties of cowpea (Vigna unguiculata (L.) Walp) in Asaba agro-ecological environment, Delta State, Nigeria. European Journal of Sustainable Development, 1, 2, 303-314 ISSN: 2239-5938.

Ali, E.A. and Mahmoud, A.M. (2013) Effect of foliar spray by different salicylic acid and zinc concentrations on seed yield and yield components of mung bean in sandy soil. Asian Journal of Crop Science, 5 (1), 33-40.

Anyia, A.O. and Herzog, H. (2004) Water-use efficiency, leaf area and leaf gas exchange of cowpeas under mid-season drought. Eur. J. Agron., 20, 327-437.

Barr, H.D. and Weatherley, P.E. (1962) A re-examination of the relative turgidity technique for estimating water deficit in leaves. Aust. J. Biol. Sci., 15, 413-428.

Bekheta, M.A. and Talaat, I.M. (2009) Physiological response of mung bean "Vigna radiata" plants to some bioregulators. Journal of Applied Botany and Food Quality, 83, 76-84.

CAAE (2012) Central Administration of Agriculture Extensionhttp://www.caae-eg.com/index.php/201212-25-10-49-19/2010-09-18-17-00-51/2011-01-1519-27-42/619-2012-05-17-09-46-16.html.

Dadson, R.B., Hashem, F.M., Javaid, I., Joshi, J., Allen, A.L. and Devine, T.E. (2005) Effect of water stress on the yield of cowpea (vigna unguiculata L. walp.) genotypes in the delmarva region of the united states. J. Agronomy \& Crop Science, 191, 210-217.

Dat, J.F., Lopez-Delgado, H., Foyer, C.H. and Scott, I.M. (1998a) Parallel change in $\mathrm{H} 2 \mathrm{O} 2$ and catalase during thermo tolerance induced by salicylic acid or heat acclimation in musturd seedlings. Plant Physiol., 116, 1351-1357.
Dat, J.F., Foyer, C.H. and Scott, I.M. (1998b) Change in salicylic acid and antioxidants during induced thermo tolerance in mustard seedlings. Plant Physiol., 118, 1455-1461.

Dow El-Madina, I.M., and Hall, A.E. (1986) Flowering of contrasting cowpea (Vigna unguiculata L. Walp.) genotypes under different temperatures and photoperiods. Field Crops Res., 14, 87-104.

Ehlers, J.D., and Hall, A.E. (1997) Cowpea (Vigna unguiculata L. Walp.). Field Crops Res., 53, 187-204.

El-Aref, H.M. (2002) In vitro selection of salt-tolerant tomato plants and the changes in gene expression under salinity stress. Assiut J. Agric. Sci., 33 (1), 23-46.

Faisal E.A. and Suliman, A.Sh.H. (2010) Effect of water stress applied at different stages of growth on seed yield and water-use efficiency of cowpea. Agric. Biol. J. N. Am., 1 (4), 534-540.

Farooq M., Basra, S.M.A., Wahid, A., Ahmad, N. and Saleem, B.A. (2009) Improving the drought tolerance in rice (Oryza sativa L.) by exogenous application of salicylic acid. J. Agron. Crop. Sci., 195, 237-246.

Farooq, M., Hussain, M., Abdul-wahid and Siddique, K.H.M. (2012) Drought Stress in Plants: An Overview.pp.1-5. In: R. Aroca (ed.), Plant Responses to Drought Stress, DOI: 10.1007/978-3642-32653-0_1, Springer-Verlag Berlin Heidelberg.

Freed R. D., Eisensmith, S.P., Everson, E.H., Weber, M., Paul, E. and Isleib, E. (1991) Mstat, C: A microcomputer program for the design management and analysis of agronomic research experiments. Michigan State University, East lansing, MI, USA.

Ghorbani Javid M., Sorooshzadeh, A., Moradi, F., Modarres Sanavy, S.A.M and Allahdadi, I. (2011) The role of phytohormones in alleviating salt stress in crop plants. Aust. J. Crop. Sci., 5, 726-734.

Gomez, K.A. and Gomez, A.A. (1984) "Statistical Procedures for Agricultural Research". 4th ed. John Wiley \& Sons Inc. New York, USA.

Gwathmey, C.O. and Hall, A.E. (1992) Adaptation to midseason drought of cowpea genotypes with contrasting senescence traits. Crop Sci 32: 773-778.

Hall, A.E. (2004) Breeding for adaptation to drought and heat in cowpea. Eur. J. Agron., 21, 447-454.

Hanaa, H.M. and Ali, E.A. (2011) Agronomic performance of seven pea (pisum sativum) genotypes with five sowing dates in sandy soil. Acta Agronomica Hungarica, 59 (4), pp. 337-347. 
Hasan, A.A. (2002) Production of legume vegetables. Al-Dar El-Arabia for publishing and distribution 302p. (in Arabic)

Israelsen, O.W. and Hansen, V.E. (1962) "Irrigation principles and practice", 3rd ed., John Wiley and Sons Inc. New York.

Jacobsen, J.V. and Beach, L.R. (1985) Control of transcription of amylase and ribosomal RNA genes in barley aleurone protoplasts by gibberellin and abscisic acid. Nature, 316, 275-277.

Jalal, R.S., Moftah, A.E. and Bafeel, S.O. (2012) Effect of salicylic acid on soluble sugars, proline and protein patterns of shara (Plectranthus tenuiflorus) plants grown under water stress conditions. Int. Res. J. Agric. Sci. Soil Sci., 2 (9), 400-407.

Janda, T., Horváth, E., Szalai, G. and Páldi, E. (2007) Role of salicylic acid in the induction of abiotic stress tolerance. In: "Salicylic Acid - A Plant Hormone", Hayat. S and A. Ahmad, (Ed.), pp.91150., Published by Springer, P.O. Box 17, 3300 AA Dordrecht, The Netherlands.

Kaydan D., Yagmur, M. and Okut, N. (2007) Effects of salicylic acid on the growth and some physiological characters in salt stressed wheat (Triticum aestivum L.). Tarim Bilimleri Dergisi, 13, 114-119.

Khavkin, E.E. and Zabrodina. M.V. (1994) Heritable variation in peroxidase and esterase isoenzyme patterns of maize somaclone. Fiziol. Rast., 41, 754-761.

Klessig, D.F. and Malamy, J. (1994) The salicylic acid signal in plants. Plant Mol. Biol., 26, 1439-1458.

Kuykendall, L.D., Hashem, F.M., Dadson, R.B., and Elkan, G.K. (2000) Nitrogen fixation. In: Encyclopedia of Microbiology, J. Lederberg, (Ed.), Vol. 3, pp.329-404. Academic Press, New York.

Laemmli, U.K. (1970) Cleavage of structural proteins during the assembly of the head of bacteriophage T4. Nature, 227, 680-685.

Larque-saavedra, A. and Martin-mex, R. (2007) Effects of salicylic acid on the bio-productivity of plants. In, Salicylic Acid - A Plant Hormone, Hayat, S. and A. Ahmad. (Ed.), pp. 15-23. Published by Springer, P.O. Box 17, 3300 AA Dordrecht, The Netherlands.

Li, Y., Wei, Y., Meng, W. and Xiaodong, Y. (2009) Climate change and drought: a risk assessment of crop yield impacts. Climate Res., 39, 31-46.

Martins, L.M.V., Xavier, G.R., Rangel, F.W., Ribeiro, J.R.A., Neves, M.C.P., Morgado, L.B. and Rumjanek, N.G. (2003) Contribution of biological fixation to cowpea: a strategy for improving seed yield in the semi-arid region of Brazil. Biol. Fertil. Soils, 38, 333-339.
Mohamed, M.F. (1996) Responce to gradient prolongedintervals of irrigation under heat-stress conditions and interspecific hybridization for five tepary bean lines”. Assiut J. Agric. Sci., 27 (4), 107-123.

Mohamed, M.F. (1999) Useful tepary and cowpea lines in rationalizing water use for pulse legume production in southern Egypt". The Third International Symposium on "Irrigation of Horticultural Crops". Lisbon-Portugal, June 28July 2, 1999. Intl. Soc. Hort. Sci., Acta Hort., 537, 813-822

Mohamed, M.F. (2003) Yield, physiological and biochemical assessments of drought resistance responses in some tepary bean lines (Phaseolus acutifolius). Assiut Univ. Bull. Environ. Res., 6 (2), 65-85.

Mohamed, M. F. and Tawfik, A.A. (2007) Intact plant, callus and field grain yield responses of tepary bean to drought. J. Agron. Crop Sci., 193, 305-312.

Muchero, W., Ehlers, J.D., Close, T.J. and Roberts, P.A. (2009) Mapping QTL for drought stress induced premature senescence and maturity in cowpea [Vigna unguiculata (L.) Walp.]. Theor. Appl. Genet., 118, 849-863.

Nielsen, C.L. and Hall, E. (1985) Responses of cowpea (Vigna unguiculata (L). Walp.) in the field to high night air temperature during flowering 11. Plant responses. Field Crops Res., 10, 181-191.

Nonami, H., (1998) Plant water relations and control of cell elongation at low water potentials, J. Plant Res., 111, 373-382.

Ogbonnaya, C.I., Sarr, B., Brou, C., Diouf, O., Diop, N.N. and Roy- Macauley, H. (2003) Selection of cowpea genotypes in hydroponics, pots, and field for drought tolerance, Crop Sci., 43, 1114-1120.

Page, A.L., Miller, R.H. and Keeney, D.R. (1982) "Methods of Soil Analysis", Parts 1 and 2. ASA Inc. and SSS A Inc., Madison, WI, USA.

Patel, P.N. and Hall, A.E. (1990) Genotypes variation and classification of cowpea for reproductive responses to high temperatures under long photoperiods. Crop Sci., 30, 614-621.

Raskin, I., (1992) Role of salicylic acid in plants. Annu. Rev. Plant Physiol. Plant Mol. Biol., 43, 439-463.

Sadoun, M.E.S., Mohamed, M.F., Abd-elrahim, G.H. and El-basyouny, M.S.S. (2016) Growth and yield of cucumber plants derived from seeds pretreated with salicylic acid. J. Boil. Chem. Environ. Sci., 11 (1), 541-561. 
Shakirova, F.M., Sakhabutdinova, A.R., Bezrukova, M.V., Fathudinova, R.A. and Fathutdinova, D.R. (2003) Changes in hormonal status of wheat seedlings induced by salicylic acid and salinity. Plant Sci., 164, 317-322.

Smith, N. (1991) "Cropwat” Model for ETo calculation using Penman-Monteith method. FAO rom, Italy.

Songhai, S., Mingxiang, P., Tin, L., Haoming, C., Mei, Z. and Jinyuan., L. (1999) Analysis of Salicylic Acid Induced Proteins in Rice. Tsinghua Sdencs and Technol., 4 (3), 1519- 1523.

Subramanian K.S, Santhanakrishnan, P. and Balasubramanian, P. (2006) Responses of field grown tomato plants to arbuscular mycorrhizal fungal colonization under varying intensities of drought stress. Sci. Hort., 107, 245-253.
Turk, K.J., Hall, A.E. and Asbell, C.W. (1980) Drought adaptation of cowpea. 1. Influence of drought on seed yield. Agron. J., 72, 413-420.

Umebese, C.E. and Bankole, A.E. (2013) Impact of salicylic acid on antioxidants, biomass and osmotic adjustments in Vigna unguiculata L. walp. during water deficit stress. African J. Biotechnol., 12 (33), 5200-5207.

Vites, F.G., (1965) Increasing water use efficiency by soil management. , ASA, Madison, Wisconsin, pp. 259-274.

(Received 28/5/2017; accepted $18 / 7 / 2017$ )

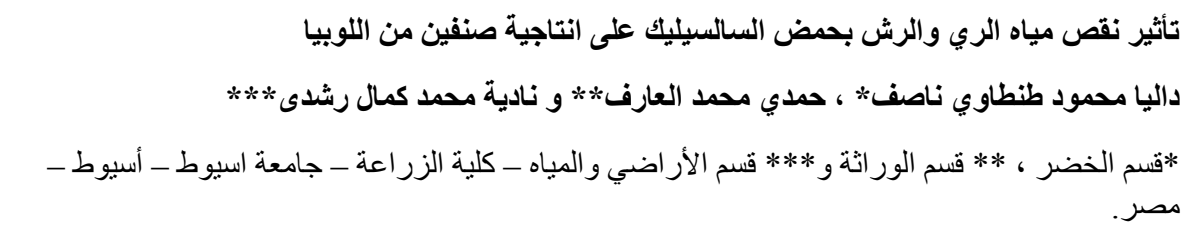

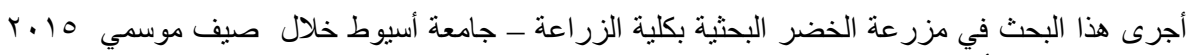

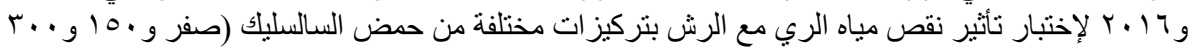

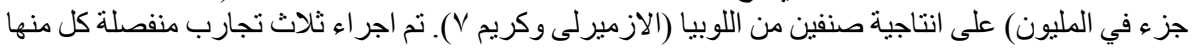

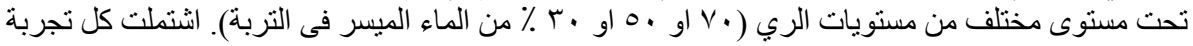

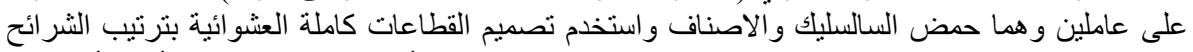

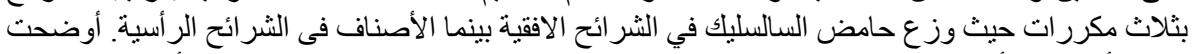

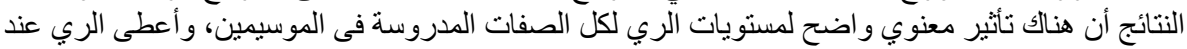

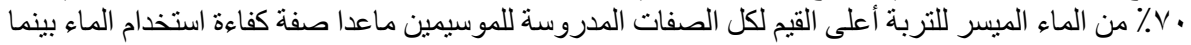

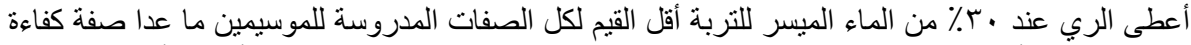

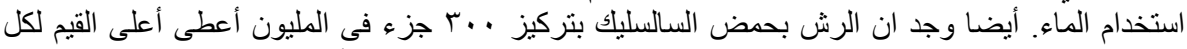

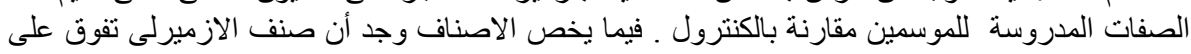

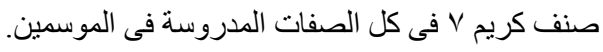

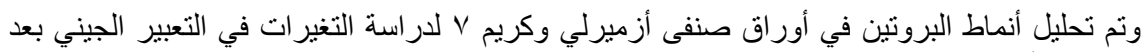

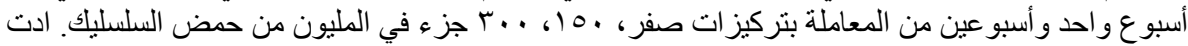

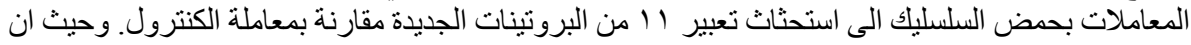

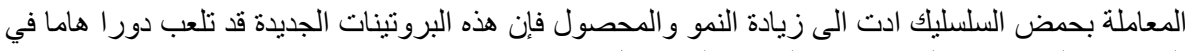
المسار ات البيوكيميائية لتحسين نمو النبات و المحسئ المصول.

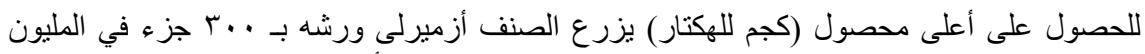

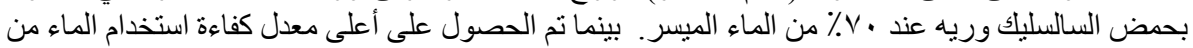

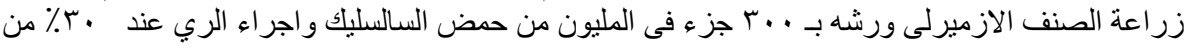

